\title{
Akuntabilitas Kinerja dalam Bingkai Tauhid Sosial: Suatu Refleksi Teologi Al Ma'Un
}

\author{
Oleh:
}

Wa Ode Rayyani ${ }^{1}$, Ahmad Abbas ${ }^{2}$

${ }^{1}$ Universitas Muhammadiyah Makassar, ${ }^{2}$ IAIN Parepare

${ }^{1}$ waode.rayyani@unismuh.ac.id, ${ }^{2}$ ahmad.abbas@stainparepare.ac.id

\begin{tabular}{l}
\hline Keywords: \\
\hline Accountability; \\
Al Ma'un \\
Teology; \\
Muhammadiyah; \\
Social Tauhid \\
\hline
\end{tabular}

Kata kunci:

Akuntabilitas;

Teologi Al

Ma'un;

Muhammadiyah;

Tauhid Sosial

\begin{abstract}
The study of this research aims to comprehend the concept and meaning of the accountability of social performance in Muhammadiyah University of Makassar. This study is qualitative using interpretive paradigm through etnomethodology approach. This study finds that Al Ma'un teology in Muhammadiyah University of Makassar is termed in the form of the servitude to God. In the university, a lot of products are the manifestation of accountability of social performance providing fundamental values including ukhuwah and sincerity in conducting the performance program, profesionalism, and independency.
\end{abstract}

\section{Pendahuluan}

Akuntabilitas secara sederhana dipahami sebagai pertanggungjawaban (Kurniawan, 2014). Akuntabilitas sosial sebagai sebuah pendekatan dalam membangun akuntabilitas yang berbasis pada perjanjian publik, dimana masyarakat biasa atau organisasi masyarakat sipil yang berpartisipasi secara langsung maupun tidak langsung 
untuk membangun akuntabilitas. Secara tradisional, bentuk akuntabilitas sosial diwujudkan dalam bentuk, advokasi, investigasi jurnalisme, partisipasi dalam kebijakan publik, penelusuran pengeluaran publik, serta semua upaya yang dilakukan untuk meningkatkan efektivitas mekanisme akuntabilitas internal pemerintah yang mana dapat dilakukan dengan melibatkan masyarakat dalam berbagai kebijakan publik. Tujuan akuntabilitas sosial ialah memperbaiki tata kelola serta meningkatkan efektivitas pembangunan dan pemberdayaan.

Dalam sejarah pendirian dan perkembangan Muhammadiyah, surah Al Ma'un memainkan peranan penting sebagai landasan dan spirit perjuangan dalam melakukan transformasi sosial. Sampai saat inipun, Al Ma'un masih menjadi dasar bagi muhammadiyah untuk melakukan berbagai macam aktivitas sosialnya. Burhani (2013) dalam tulisannya menyebutkan bahwa dari rahim teologi Ma'un lah, sampai saat ini muhammadiyah telah memiliki banyak sekolah, rumah sakit, dan berbagai fasilitas kepentingan umat lainnya. Oleh sebab itu, membincangkan perkembangan muhammadiyah dan amal usahanya berarti membincangkan mengenai bagaimana urgensi teologi Al Ma'un dalam menjaga eksistensi organisasi hingga saat ini atau dalam istilah Syafi'i Ma'arif disebut sebagai Al-Ma'unisme (Huda, 2011).

Dalam berbagai literatur tafsir, surah Al Ma'un dipandang sebagai landasan teologis umat Islam, terutama Muhammadiyah dalam membebaskan kaum mustad'afin dari keterbelengguan sistem yang menindas, kebodohan, kemiskinan dan berbagai macam patologi sosial lainnya. Dalam konteks ber-muhammadiyah, spirit al ma'un tersebut diterjemahkan dalam tiga pilar utama, yakni healing (pelayanan kesehatan), schooling (pendidikan), dan feeding atau pelayanan sosial (Burhani, 2013).

Akuntabilitas kinerja organisasi sesungguhnya memiliki akar filosofis dan substansial pada akuntabilitas yang bersifat sosial dalam kehidupan sesama manusia. Muhammadiyah secara organisatoris telah menyadari hakikat dari dimensi sosial kehidupan manusia ini melalui kajiannya atas ayat Al Qur'an surah Al Ma'un yang populer dengan sebutan teologi Al Ma'un. Teologi Al Ma'un menjelaskan secara filosofis bagaimana sisi sosial manusia memegang peranan penting dalam kehidupan.

Dalam era kekinian, tantangan yang dihadapi manusia semakin kompleks. Dinamika patologi sosial, mulai dari perilaku amoral yang kian marak di tengah masyarakat sampai pada kemiskinan dan kebodohan yang masih mengintai masyarakat Indonesia merupakan tantangan tersendiri bagi Muhammadiyah untuk 
mengejawantahkan spirit Al Ma'un dalam kehidupan sehari-hari. Jika ini ditarik dalam ranah kehidupan manusia secara umum, terutama dalam konteks penelitian ini, maka dapatlah dikatakan bahwa tanggung jawab sosial manusia bukan hanya predikat yang melekat secara individu semata. Artinya, manusia dalam mengemban visi dan misi sosialnya sebagai khalifah di muka bumi tidak hanya sebagai individu semata. Sebagai makhluk yang niscaya selalu ingin hidup bersama dalam naungan organisasi, manusia juga memiliki tanggung jawab sosial sebagai sebuah organisasi. Bukankah memang, akan lebih mudah tercapai tujuan sosial manusia jika ia dilakukan secara bersama-sama?.

Tanggungjawab sosial perguruan tinggi bukanlah semata-mata diwujudkan dalam bentuk aktivitas-aktivitas yang bermanfaat bagi kepentingan masyarakat semata, sebagaimana yang telah diformulasikan dalam visi dan misi. Tanggung jawab sosial perguruan tinggi juga menuntut bahwa setiap produk sosial yang dirasakan manfaatnya oleh masyarakat juga menyisakan ruang interaksi (pengawasan, akses informasi, dan sebagainya) antara perguruan tinggi dan masyarakat. Interaksi antara perguruan tinggi dan masyarakat terkait dengan pelayanan sosial yang diberikan akan menciptakan akuntabilitas sosial yang efektif bagi perguruan tinggi. Konsep tentang akuntabilitas sosial sendiri nampaknya belum begitu populer di perguruan tinggi. Akuntabilitas sosial selama ini merupakan gagasan yang menjadi sorotan dalam penyelenggaraan pemerintahan pada umumnya, sebab pemerintahlah yang menjadi pelayan utama masyarakat.

Selayaknya entitas pemerintah, perguruan tinggi sebagai institusi yang memberikan pelayanan publikpun mesti memiliki akuntabilitas sosial. Apalagi hal ini telah diperjelas dalam tujuan sosial pendirian Universitas Muhammadiyah Makassar. Dengan demikian, akuntabilitas sosial menjadi media yang menjembatani pihak Universitas Muhammadiyah Makassar dan masyarakat luas melalui produk-produk sosial yang diberikan. Penelitian ini akan mengurai bagaimana konsep akuntabilitas sosial organisasi dipahami dan dipraktikkan di Universitas Muhammadiyah Makassar. Selama ini, akuntabilitas selalu menjadi sorotan bagi para akademisi dan peneliti untuk diaktualisasikan ke dunia perusahaan dan lembaga pemerintahan, padahal lembaga pendidikan sendiri belum tentu mewujudkan dengan baik mengenai konsep akuntabilitas sosial. 


\section{Metode}

Penelitian ini menggunakan paradigma interpretif etnometodologi untuk memahami dan memaknai konsep akuntabilitas sosial Universitas Muhammadiyah Makassar. Etnometodologi menitikberatkan pada pemahaman tentang perilaku keseharian individu dalam lingkungan sosialnya dan bagaimana mereka menyelesaikan permasalahan atau pekerjaan yang mereka hadapi (Coulon, 2008). "Daily activity" merupakan kata kunci dan menjadi ciri khas etnometodologi. Informan terdiri dari Unsur Pimpinan Universitas, Fakultas, Kepala Biro Keuangan serta anggota Badan Pelaksana Harian (BPH). Seluruh informan merupakan informan kunci dalam memberikan sumber informasi utama yang kami anggap relevan dan dibutuhkan terkait tema penelitian ini.

Tabel 1. Informan Penelitian

\begin{tabular}{|l|l|}
\hline \multicolumn{1}{|c|}{ Nama } & \multicolumn{1}{c|}{ Jabatan } \\
\hline Prof H. Irwan Akib M.Pd & Rektor Universitas Muhammadiyah Makassar \\
\hline H. Abd Rahman Rahim & Wakil Rektor 1 Universitas Muhammadiyah Makassar \\
\hline Dr. Rosleny & Wakil Rektor 2 Universitas Muhammadiyah Makassar \\
\hline Dr. H. Abdul Rahim Nanda & Wakil Rektor 4 Universitas Muhammadiyah Makassar \\
\hline Ir. Darwis Lantik & Anggota BPH Universitas Muhammadiyah Makassar \\
\hline Ibu Ruly & $\begin{array}{l}\text { Direktur Keuangan Universitas Muhammadiyah } \\
\text { Makassar }\end{array}$ \\
\hline
\end{tabular}

Untuk mengumpulkan data empiris, kami menggunakan tiga teknik pengumpulan data, yaitu dengan teknik observasi, indepth interview dan dokumentasi. Observasi kami lakukan sejak pertama kali memasuki situs penelitian hingga penelitian ini berakhir. Proses wawancara direkam dengan menggunakan alat perekam. Kami juga menambahkan beberapa catatan lapangan dan catatan penting lainnya yang sangat membantu memperoleh data yang lebih akurat serta membuat fieldnote (catatan lapangan), dan transkrip hasil wawancara. Data non-empiris didapatkan melalui olah pikir dan olah rasa (intuisi) dalam upaya menemukan makna indeksikalitas dan refleksikalitas yang disajikan dalam setting alamiah dan natural di Universitas Muhammadiyah Makassar. 
Metode analisis data mengacu pada model interaktif yang dikembangkan oleh Miles dan Huberman (1984) yang prosesnya terdiri atas koleksi data, reduksi data, penyajian data dan pengambilan kesimpulan/verifikasi. Proses analisis data dilakukan secara terus menerus selama penelitian berlangsung. Seperti yang diungkapkan oleh Miles dan Huberman (1984) bahwa aktivitas dalam analisis data kualitatif dilakukan secara interaktif dan berlangsung secara terus menerus sampai tuntas, hingga datanya jenuh. Data yang jenuh ditandai dengan tidak diperolehnya lagi data atau informasi baru. Terkait dengan metode penelitian yang digunakan maka analisis data juga dilakukan dengan mengikuti kaidah dalam penelitian etnometodologi yaitu dengan memperhatikan indeksikalitas dan refleksikalitas. Indeksikalitas dan refleksivitas merupakan konsep penting dalam melakukan analisis data etnometodologi (Coulon, 2008). Gamar dan Djamhuri (2015) menyebut indeksikalitas sebagai kelompok tersurat, yakni yang merupakan kalimat terindeks yang berisi pemahaman para aktor dalam memahami peran mereka, dan refleksikalitas sebagai kelompok tersirat, yakni yang merupakan makna yang timbul diluar batas kesadaran para aktor, dan keterkaitan makna antara satu peristiwa dengan peristiwa lainnya. Dengan begitu, maka proses analisis seluruhnya dalam penelitian ini meliputi enam tahapan, yaitu koleksi data, reduksi data, penyajian (display) data, indeksikalitas, refleksikalitas, verifikasi/ kesimpulan.

\section{Hasil dan Pembahasan}

\section{Kepekaan Sosial dan Kehakikian Makna Akuntabilitas Kinerja}

Sudah menjadi fitrah bagi manusia sebagai makhluk Allah ta'ala yang memperoleh anugerah kepekaan untuk saling menebar cinta dan kasih sayang kepada sesama. Kepekaan tersebut diaktualisasikan dalam berbagai bentuk. Di level organisasi, Muhammadiyah telah menggagas berbagai bentuk kepekaan sosial tersebut. Pada awal pendiriannya, Kiai Ahmad Dahlan fokus untuk mengurusi masalah kemiskinan yang kala itu merajalela di lingkungan tempat ia tinggal. Saat ini, masalah yang diihadapi oleh masyarakat muncul dalam wajah yang beragam dan memiliki substansi yang sama. Kemiskinan, kebodohan dan berbagai patologi sosial lainnya menjelma dalam berbagai bentuk.

Muhammadiyah saat inipun hadir dalam kekuatan yang berbeda, terutama dalam hal pendidikan yang ditandai dengan lahirnya berbagai perguruan tinggi Muhammadiyah di seluruh wilayah Indonesia. Sebagai pilar kemajuan organisasi Muhammadiyah dalam 
bidang pendidikan, Universitas Muhammadiyah Makassar berusaha melakukan transformasi, baik dalam lingkungan internal universitas maupun eksternal (sosial masyarakat). Kinerja dalam bentuk transformasi sosial masyarakat dilakukan sebagai wujud akuntabilitas organisasi yang sesungguhnya. Upaya untuk mencerdaskan generasi muda secara intelektual dilakukannya secara berkesinambungan hingga sekarang. Segala upaya peningkatan kualitas sudah dilakukan oleh semua pihak, baik para tenaga pengajar maupun pengurus di tataran strukural. Ketersinambungan semangat dalam mengembangkan tradisi intelektual dan spiritual dalam lingkungan universitas bagi para civitas akademika dibarengi juga dengan semangat melakukan transformasi sosial masyarakat yang masih terkait langsung dengan pendidikan. Terkait dengan hal ini, Bapak Abdul Rahman Rahim, Wakil Rektor I dalam sebuah wawancara memberi penuturan sebagai berikut:

“....Yaa kami kira, apapun juga yang namanya dilakukan oleh manusia itu tidak pernah mencapai harapan yang semestinya yaa...jadi, kualitas itu sendiri kan itu tidak ada akhirnya, yang ada itu kualitas berkelanjutan, mutu yang berkelanjutan. Jadi kalau terkait ini maka tidak ada pilihan lain kecuali secara terus menerus peningkatan mutu peningkatan kinerja di lakukan..."

Pernyataan tersebut mengandung beberapa makna indeksikalitas yang terkait dengan upaya Universitas Muhammadiyah Makassar dalam menjaga kualitasnya secara berkesinambungan sebagai bentuk aktualisasi visi dan misi Muhammadiyah itu sendiri. Pertama, kualitas merupakan sesuatu yang tidak pernah memiliki akhir. Penggalan kalimat “...jadi, kualitas itu sendiri kan itu tidak ada akhirnya, yang ada itu kualitas berkelanjutan, mutu yang berkelanjutan..." sesungguhnya menegaskan bahwa kualitas harus selalu diperbaharui, ditingkatkan setiap saat dalam sebuah organisasi. Kualitas bukanlah sesuatu yang statis, apalagi stagnan. Kualitas adalah sesuatu yang dinamis, mengikuti kompleksitas perkembangan masalah yang dihadapi manusia. Hal tersebut memang sudah disinyalir oleh Burhani (2004) bahwa eksistensi Muhammadiyah akan terjaga jika ia mampu meningkatkan kualitasnya seiring dengan perkembangan zaman. Kedua, ketersinambungan kualitas meniscayakan bahwa setiap elemen dalam organisasi untuk senantiasa mengembangkan mutu secara individual. Mutu Universitas Muhammadiyah Makassar dalam konteks ini tidak akan meningkat ketika tidak didukung dengan peningkatan mutu di level anggota organisasi. Dalam menjawab peningkatan mutu secara berkesinambungan, Universitas Muhammadiyah Makassar memiliki ikhtiar yang cukup untuk dapat memberikan kualitas pelayanan terbaik bagi segenap civitas 
akademika maupun masyarakat secara umum. Sementara itu, refleksivitas yang bisa dipahami dalam pernyataan tersebut adalah bahwa 'melayani' merupakan intisari dari kehidupan ini. Penghambaan merupakan ruh dari kehidupan, dan sebagai makhluk, manusia selalu diingatkan untuk selalu meningkatkan kualitas penghambaan di hadapan Allah swt. Demikian juga dalam hal pelayanan terhadap sesama, manusia dituntut untuk selalu memberikan yang terbaik yang ia miliki, mengevaluasi apa yang sudah diberikan, dan kemudian memperbaharui lagi kualitasnya agar tetap terjaga.

Niat dan ikhtiar untuk meningkatkan kualitas pelayanan di Universitas Muhammadiyah Makassar itu sendiri merupakan bentuk akuntabilitas universitas dalam rangka mewujudkan visi dan misi Muhammadiyah. Basis nilai dakwah yang diemban menjadikan Universitas Muhammadiyah Makassar tidak hanya melakukan fungsi tridharma-nya semata, melainkan juga melakukan pencerahan-pencerahan terhadap umat manusia secara luas. Pencerahan-pencerahan yang dilakukan dimaksudkan untuk menciptakan sebuah transformasi sosial bagi masyarakat, dan hal tersebut diwujudkan dalam bentuk dakwah. Wujud akuntabilitas inilah yang sesungguhnya dimaknai oleh Universitas Muhammadiyah Makassar sebagai 'the real accountability' dalam organisasi bahwa akuntabilitas organisasi adalah pertanggungjawaban terhadap sesama manusia, dan pertanggungjawaban itu mengikuti kodrat manusia sebagai makhluk Tuhan yang memiliki tujuan sosial. Prof Irwan Akib, Rektor Universitas Muhammadiyah Makassar, dalam sebuah kesempatan menuturkan hal sebagai berikut:

“...Ciri khas Unismuh ini bahwa perguruan tinggi ini selain sebagai lembaga pendidikan, juga mengemban misi dakwah persyarikatan, karna itu dalam segala aktivitas yang dilakukannya tidak bisa lepas dari dakwah. Ini yang membedakan unismuh dengan perguruan tinggi lainnya. Unismuh tidak hanya mengemban pancadharma perguruan tinggi, namun juga melakukan pencerahan-pencerahan bagi ummat..."

Penuturan Rektor tersebut secara tegas menguatkan eksistensi Universitas Muhammadiyah Makassar sebagai lembaga pendidikan sekaligus menjadi media pencerahan bagi masyarakat. Ada beberapa indeksikalitas makna yang terkandung dalam pernyataannya ialah bahwa akuntabilitas organisasi tidak bisa diwujudkan dalam internal Universitas saja melainkan juga diwujudkan dalam bentuk relasi terhadap sesama; termasuk juga antara Universitas dan masyarakat. Hal ini berangkat dalam kerangka berpikir bahwa Universitas Muhammadiyah merupakan media pencerahan bagi umat. Jika akuntabilitas sebelumnya dimaknai dalam lingkup internal Universitas, maka akuntabilitas dalam konteks ini lebih menyentuh kehidupan rill masyarakat. 
Secara reflektif, Pak Akib menyadari bahwa sudah menjadi tugas individu manusia maupun organisasi untuk menebarkan dakwah terhadap sesama. Apalagi, Universitas Muhammadiyah Makassar mengemban amanah besar persyarikatan untuk tidak sekedar mencerdaskan generasi melainkan juga mencerdaskan spiritual umat melalui gerakan-gerakan dakwah. Pada titik ini, dapatlah dipahami bahwa akuntabilitas kinerja organisasi pada universitas, secara hakiki berakar pada keyakinan bahwa setiap amanah yang diberikan oleh Allah swt, yakni dakwah amar ma'ruf nahi munkar harus ditegakkan sehingga universitas bisa menjadi media pencerahan bagi umat.

Kiai Ahmad Dahlan sendiri menekankan bahwa pendidikan Islam merupakan suatu wadah untuk menuju kepada kesempurnaan budi, yaitu mengerti baik dan buruk, benar dan salah, kebahagiaan dan penderitaan. Tujuan pendidikan dalam konsepsi Kiai Ahmad Dahlan ialah melahirkan individu yang utuh menguasai ilmu agama dan ilmu umum, material dan spiritual serta dunia dan akhirat. Oleh karenanya, di Madrasah atau sekolah-sekolah muhammadiyah, pengajaran tentang ilmu agama dan ilmu umum diberikan secara proporsional (Mustapa, 2014).

\section{Islam Dan Transformasi Sosial: Implementasi Teologi Al Ma'un}

Kiai Ahmad Dahlan sebagai pendiri Muhammadiyah sendiri tidak lantas hanya mengajarkan falsafah surah Al Ma'un tersebut dan implementasinya secara tradisional. Sejarah mencatat bahwa Kiai Ahmad Dahlan juga menggandeng Budi Utomo dan Kraton Yogyakarta dalam merealisasikan visi dan misi Muhammadiyah. Ini membuktikan bahwa sesungguhnya Muhammadiyah inklusif dan berpikir visioner dalam mewujudkan citacitanya.

Keutamaan teologi Al ma'un dalam menginspirasi gerakan persyarikatan Muhammadiyah secara umum dan Universitas Muhammadiyah Makassar secara khusus, dijelaskan oleh Pak Lantik (Anggota BPH) dalam petikan wawancara berikut ini:

“...Hmm,, teologi al ma'un ini,,, kami kira bukan hanya milik Muhammadiyah saja yaa... semua organisasi islam yang berorientasi pada perubahan sosial itu kan landasannya ya al ma'un itu.... Jadi surah itu memang diturunkan agar supaya umat islam menyadari ada tanggung jawab sosial yang diembannya kan...? Kan di luar Indonesia... banyak pemikirpemikir juga menggagas perubahan sosial.. ya berangkatnya juga dari al ma'un itu. Kiai Dahlan pun melakukan hal yang sama di Indonesia dan sepengetahuan kami...eee..Kiai Dahlan juga terinspirasi oleh para tokohtokoh dari luar kan... jadi,,, al ma'un ini begitu luas lingkupnya..." 
Petikan wawancara menjelaskan beberapa makna indeksikalitas. Pertama, tidak dapat disangkal bahwa landasan gerak perjuangan Muhammadiyah, tidak terkecuali Universitas Muhammadiyah Makassar dibangun dari spirit teologi Al Ma'un. Gerakan perubahan sosial dalam berbagai aspek kehidupan yang dipelopori oleh Muhammadiyah berangkat dari pemahaman dan penghayatan secara mendalam atas surah Al Ma'un tersebut. Tidaklah heran jika kemudian pemahaman dan penghayatan yang mendalam tersebut dijewantahkan dalam berbagai bentuk, seperti pendirian rumah sakit, pendirian sekolah, dan lain sebagainya. Dalam konteks kekinian, wajah aplikatif dari teologi al Ma'un tersebut kemudian disebut teologi Mustad'afin, teologi kaum yang tertindas. Teologi Mustad'afin bukanlah sebuah teologi baru dalam dinamika gerakan perubahan dalam islam, tetapi ia merupakan konsep baru sebagai bentuk penafsiran yang lebih baru dari teologi Al Ma'un (Huda, 2011). Kedua, indeksikalitas yang bisa dipahami dari penggalan pernyataan adalah bahwa di manapun berada, kader-kader Muhammadiyah memiliki kewajiban untuk melakukan perubahan sosial di lingkungan sekitarnya. Resapan spirit Al Ma'un atau teologi Mustad'afin tersebut harus selalu dibuktikan dengan karya-karya nyata bagi setiap kader persyarikatan. Universitas Muhammadiyah Makassar sebagai amal usaha Muhammadiyah sudah semestinya juga mengilhami spirit ini.

Secara spesifik, Universitas Muhammadiyah Makassar memang memiliki beberapa bentuk kegiatan yang bersifat sosial. Namun demikian, ruh sosial yang termaktub dalam kegiatan kampus tidak lepas dari esensinya sebagai lembaga pendidikan. Misalnya, penuturan Pak Lantik di bawah ini yang menjelaskan bagaimana bentuk riil kepedulian Universitas Muhammadiyah Makassar:

"...eee,, kalau kegiatan sosial itu kan memang di bawah persyarikatan Muhammadiyah langsung... misalnya PWM atau PDMnya... rumah sakit, sekolah, dan lain sebagainya itu diinisiasi oleh pimpinan wilayah atau daerah yaa.. tapi kalau di tingkat amal usaha seperti unismuh ini.. kegiatannya kan tidak jauh-jauh dari pendidikan.. misalnya, di lingkungan kampus ini, kami punya dua sekolah binaan yaitu SMP dan SMA Muhammadiyah Unismuh... tidak hanya itu, kampus juga punya desa binaan... dan itu adalah wujud kepedulian Unismuh terhadap pendidikan di masyarakat,,, jadi bukan hanya di dalam kampus saja... dan kami juga mengadakan program dakwah untuk setiap tahunnya..seperti mengirimkan para muballigh untuk menyiarkan dakwah di lingkungan luar kampus.. nah, kalau kaitannya dengan perubahan sosial,,, yaa unismuh berperan dalam bidang pendidikan... artinya yaa,, bekal-bekal yang diterima oleh mahasiswa,,, dan aktivitas sosial organisasi di tingkat mahasiswa bisa menjadi bekal berharga... kan nanti mereka bisa kembali dan melakukan perubahan di tempatnya masing-masing..." 
Pak Lantik secara komprehensif menjelaskan bahwa kegiatan sosial memang menjadi bagian yang tidak terpisahkan dari Muhammadiyah. Akan tetapi, yang perlu disadari bentuk kegiatan sosial tersebut, misalnya pendirian rumah sakit dan panti asuhan, bahkan Universitas sendiri berada di bawah Persyarikatan Muhammadiyah. Oleh karena itu, secara spesifik, Universitas bergerak dalam bidang pendidikan, sekalipun ruang lingkupnya tidak terbatas pada pengajaran di kampus. Dalam pernyataan tersebut, dapat diketahui bahwa kepedulian sosial Universitas Muhammadiyah Makassar diwujudkan dengan cara membina desa dan sekolah di lingkungan Universitas Muhammadiyah Makassar sendiri.

Keberadaan Universitas Muhammadiyah Makassar juga membawa berkah bagi lingkungan sosialnya. Sebagai salah satu universitas swasta terbesar di Makassar, Universitas Muhammadiyah Makassar banyak memberikan kontribusi yang positif dalam meningkatkan ekonomi masyarakat yang ada disekitarnya. Mulai dari pemilik kos-kosan, warung makan, transportasi rakyat seperti ojek dan bentor, fotokopi, hingga penjualan alat tulis memperoleh manfaat dari keberadaan kampus Universitas Muhammadiyah Makassar. Sebagai contoh, wujud akuntabilitas sosial adalah pemberian izin untuk membuka kantin di dalam lingkungan kampus, penjualan alat tulis maupun keperluan fotocopy, bahkan di depan masjid kampus, ada penjual bakso dengan gerobak dorong yang setiap hari berjualan di sana. Inti tentu terlihat bahwa keberadaan Universitas Muhammadiyah Makassar tidak bisa dilepaskan dari masyarakat sekitar tempatnya berada. Dengan demikian, Universitas membangun hubungan yang harmonis dengan masyarakat sekitarnya. Hubungan ini sebagai salah satu bentuk pertanggungjawaban sosial Universitas terhadap sesama manusia.

Pernyataan Pak Darwis Lantik juga didukung oleh hasil wawancara bersama Bapak Abdul Rahman Nanda:

“...Naah.. kalo di sini [unismuh Makassar], semua kader menyadari betul tentang teologi al ma'un itu... Cuma pada prakteknya kan beda-beda... misalnya kampus dengan amal usaha yang lain berbeda kan..kalo rumah sakit itu kan melayani kebutuhan kesehatan masyarakat...mungkin juga ada program pengobatan gratis dan lainnya... kalo unismuh... ya kita ingin melakukan perubahan melalui pendidikan dan dakwah... harapan besarnya,, dari pendidikan itu,,, nanti akan menciptakan perubahan di masyarakat kelak.. dan tujuan Muhammadiyah bisa terwujud dan semakin meluas nanti lingkup pergerakannya..." 
Dari pernyataan tersebut, Universitas Muhammadiyah Makassar tetap memiliki komitmen untuk mewujudkan akuntabilitas sosialnya melalui dunia pendidikan. Dari dunia pendidikan, Universitas Muhammadiyah Makassar berharap dapat memberikan bekal kepada para civitas akademika berupa nilai-nilai Islam dan pada akhirnya, bekal tersebut akan digunakan untuk melakukan perubahan sosial di masyarakat sehingga citacita besar Muhammadiyah mampu tercapai.

Dalam konteks pemikiran yang lebih global, Muhammad Abduh, seorang cendekiawan muslim kontemporer, memandang pendidikan sebagai sebuah sarana perubahan masyarakat secara makro yang meyakini bahwa pendidikan di bawah naungan Islam tidak spenuhnya tergantung pada sistem barat tetapi memadukan atau menyerap rasionalitas barat dalam pendidikan Islam akan menghasilkan perubahan dalam kehidupan umat Islam sendiri (Normuslim, 2013). Oleh karena itu, visi perubahan dan pencerahan yang diemban oleh Universitas Muhammadiyah melalui dunia pendidikan dapatlah dikatakan menyerap spirit pemikiran pembaharuan para cendikiawan muslim di dunia dan perubahan dan pencerahan itu masih dapat dirasakan hingga hari ini.

\section{Falsafah Nilai Akuntabilitas Kinerja Sosial: dari Tuhan kembali ke Tuhan}

Akuntabilitas sosial yang ditunjukkan oleh Universitas Muhammadiyah Makassar yang didasarkan pada spirit al-ma'un dan termaktub beberapa nilai mendasar yang terkandung di dalamnya menjadi faktor pendorong bagi terwujudnya akuntabilitas sosial Universitas Muhammadiyah Makassar. Nilai-nilai yang melandasi praktik akuntabilitas sosial Universitas Muhammadiyah Makassar antara lain sebagai berikut:

a. Nilai keikhlasan dan ukhuwah (persaudaraan).

Nabi sendiri, Muhammad SAW, telah menegaskan bahwa sebaik-baik diri seorang muslim adalah yang paling memberi manfaat bagi orang lain, atau muslim lainnya. Allah SWT telah mengutusnya sebagai rahmat seluruh alam semesta, termasuk di dalamnya seluruh umat manusia tanpa mengenal status dan batasan keyakinan. Prinsip ukhuwah di Universitas Muhammadiyah Makassar adalah membangun persaudaraan, kebersamaan dan kerjasama. Manifestasi ukhuwah di universitas ini tampak pada kegiatan pengkaderan organisasi Muhammadiyah baik untuk tingkat mahasiswa, karyawan maupun dosen. Beberapa organisasi otonom yang ada di dalam kampus seperti tapak suci, hizbul wathan dan Ikatan Mahasiswa Muhammadiyah (IMM). Internal universitas juga tergabung dalam organisasi otonom Muhammadiyah seperti aisyiah 
(untuk organisasi perempuan), Pemuda Muhammadiyah. Kegiatan-kegiatan tersebut mempererat rasa persaudaraan dan kebersamaan dalam ber-Muhammadiyah, saling mengenal, rasa saling menyayangi sebagai saudara muhammadiyah. Nilai-nilai ukhuwah tersebut menumbuhkan rasa saling percaya, kerjasama dan koordinasi pekerjaan sehingga menciptakan sebuah kesatuan unit kerja yang solid. Itulah mengapa dalam kegiatan muktamar, warga muhammadiyah sangat antusias menyambutnya. Karena tingginya rasa ukhuwah yang terjalin sesama warga muhammadiyah. Sikap menjaga ukhuwwah dalam konteks merealisasikan akuntabilitas sosial tentu akan berhasil jika semuanya didasarkan pada nilai keikhlasan. Ikhlas berarti melakukan sesuatu karena menyadari bahwa itu merupakan tanggung jawabnya, tanpa menunggu perintah ataupun mengharapkan sesuatu di balik perbuatannya tersebut. Perpaduan nilai ukhuwwah dan ikhlas akan mempermudah Universitas Muhammadiyah Makassar dalam merealisasikan akuntabilitas sosial mereka. Bapak Abdul Rahim Nanda, dalam suatu kesempatan menuturkan hal tersebut melalui pernyataan:

“...nilai dasar yang dianut di sini adalah ukhuwwah dan ikhlas... ukhuwwah itu kami kira menjadi hal yang sangat prinsip karena sejatinya semua muslim kan bersaudara dan saling tolong menolong satu sama lainnya...Dalam kampus, semua dosen maupun pimpinan harus saling menjaga ukhuwwah islamiyah satu sama lain..Kalo ikhlas ya berarti tidak perlu tunggu komando. Yang penting sudah ada strukturnya, program kerja,, dan job des-nya masingmasing.. semua harus ikhlas melaksanakan apa yang sudah jadi tanggungjawabnya.. kalo berkaitan dengan hal di luar kampus ya,, kita juga menyadari bahwa semua manusia di luar sana adalah saudara kita semua, yang patut dibantu ketika susah,, dan ikhlas.. itu intinya..."

Dari pernyataan tersebut, setidaknya terdapat sebuah makna indeksikalitas bahwa nilai ukhuwah islamiyah dan ikhlas menjadi nilai prinsip yang membentuk akuntabilitas sosial. Ukhuwah mengikat sesama umat muslim, bahkan diluar muslim dalam wujud saling tolong menolong, mengasihani sesama, saling melindungi dari ancaman dan lain sebagainya. Sementara, untuk melakukan semua itu, setiap pribadi muslim harus sedapat mungkin menanamkan nilai-nilai keikhlasan didalam sanubarinya.

b. Nilai amanah.

Sebagaimana telah disinggung sebelumnya bahwa kehidupan dan segala pernakpernik yang dimiliki oleh manusia merupakan titipan dari Allah swt. Dalam menyelenggarakan aktivitas di kampus, universitas harus memiliki kesadaran demikian. Jika tidak, maka semua bentuk aktivitas tidak memiliki nilai, orientasi serta tujuan yang 
jelas. Berpegang kepada prinsip kepemilikan mutlak Tuhan atas segalanya, maka universitas akan lebih jelas dalam mencapai tujuan sosialnya, yakni kesejahteraan yang menyentuh seluruh lapisan masyarakat.

c. Profesionalisme dan kemandirian.

Dalam pengelolaan sebuah organisasi, profesionalisme merupakan prinsip yang harus dijunjung tinggi. Profesionalisme secara sederhana bisa dimaknai sebagai bekerja sesuai dengan bidang atau kemampuan, atau bekerja dengan penuh dedikasi terhadap profesi yang digelutinya. Dalam mewujudkan akuntabilitas kinerja sosial Universitas Muhammadiyah, profesionalisme dibuktikan dengan konsistensi universitas dalam menebarkan perubahan melalui bidang pendidikan. Upaya perubahan dalam bidang pendidikan seperti sekolah dan desa binaan, merupakan wujud profesionalisme dalam bekerja. Pada ranah yang lain, profesionalisme dalam bekerja juga dapat berwujud apresiasi dalam bentuk insentif atau reward atas prestasi yang diraih dan punishment untuk pelanggaran yang dilakukan oleh anggota organisasi. Dengan demikian, setiap anggota akan merasa bahwa kemampuan mereka memiliki tempat dalam organisasi. Pernyataan terkait dengan hal ini disampaikan oleh Pak Abdul Rahman Nanda:

“...Profesionalisme di sini kita junjung yaa.. misalnya,, dalam pengelolaan kampus. Kalo ada mahasiswa yang masuk, bayar SPP. Kinerja dosen... harus digaji.. setiap karyawan yang bekerjapun harus ada penghasilannya.. nah dalam kondisi seperti ini,,prinsip profesionalisme setiap saat harus dijunjung tinggi..."

Informan mengungkapkan makna profesionalisme dalam konteks Universitas Muhammadiyah Makassar sebagai bentuk apresiasi atas apa yang telah dikerjakan oleh anggota organisasi. Kaitannya dengan akuntabilitas sosial Universitas Muhammmadiyah Makassar, profesionalisme bisa dilihat pada bagaimana Universitas berupaya mencerdaskan (akademik dan spiritual) civitas akademika (mahasiswa) melalui proses pembelajaran di kelas maupun aktivitas pelayanan lainnya sebagai wujud pemenuhan hak-hak mereka. Demikian juga halnya dengan produk sosial universitas seperti sekolah dan desa binaan, semua dikelola dalam prinsip profesionalisme, pemenuhan hak-hak serta penyelenggaraan pelayanan yang bermutu.

d. Nilai efektif dan efisiensi.

Efektif diartikan sebagai dapat membawa hasil atau berhasil guna dan efisiensi diartikan sebagai ketepatan cara dalam mengerjakan. Kedua definisi tersebut memiliki keterkaitan satu sama lain, tujuan yang sama, yakni tidak membuang waktu, tenaga dan 
biaya dalam mendapatkan sesuatu yang maksimal atau mencapai tujuan organsiasi. Dalam bahasa yang sederhana, efektivitas berarti melakukan aktivitas yang bermanfaat dan tidak sia-sia, sementara efisien berarti tidak boros dalam menggunakan tenaga, waktu dan biaya dalam mengerjakan seesuatu (tepat guna). Ketepatgunaan dalam bekerja dijelaskan oleh Pak Abdul Rahim Nanda dalam petikan wawancara sebagai berikut:

“...kalo efektif itu yaa...jangan bekerja sia-sia. Harus ada hasilnya, yang hasilnya itu betul-betul bermanfaat, terutama, banyak hal, tapi yang utama karna kita ini pelayanan bagi calon sarjana, maka dia harus betul-betul mencapai tujuannya, yaitu pada akhirnya nanti ke pancadharma perguruan tinggi itu kembali..." kalo efisien itu kaitannya dengan bagaimana kita melakukan upaya penghematan, baik dalam anggaran maupun sumber daya lain yang dimiliki, tidak boros, tapi juga tidak mengurangi target atau kualitas pelayanan kita terhadap mahasiswa maupun tujuan lainnya universitas..."

Universitas Muhammadiyah Makassar memegang prinsip efektifitas dan efisiensi, yakni bahwa setiap pekerjaan tidak boleh dilakukan secara sia-sia atau tidak bermanfaat dengan prinsip penghematan. Dalam memberikan pelayanan bagi seluruh civitas akademika, kedua nilai ini harus dipegang erat. Dalam petikan wawancara, informan secara spesifik menjelaskan efektivitas efisiensi dalam lingkup internal universitas, yakni pelayanan terhadap para calon sarjana (mahasiswa) yang merupakan bagian tanggung jawab dari pancadharma sebuah perguruan tinggi. Akuntabilitas sosial Universitas Muhammadiyah Makassar dalam kaitannya dengan prinsip dan nilai efektifitas dan efisiensi menghendaki adanya kesadaran bersama bahwa setiap program yang bersifat sosial atau berorientasi sosial mestinya dilakukan secara tepat guna, tepat sasaran dan tidak menghambur-hamburkan aset yang dimiliki (biaya, waktu, dan tenaga). Produk-produk sosial Univesitas Muhammadiyah Makassar di bidang pendidikan sebagaimana telah disebutkan sebelumnya merupakan wujud nyata dari efektifitas dan efisiensi, yakni bahwa semuanya tidak dilakukan dengan sia-sia melainkan sarat nilai, sarat guna dan yang paling mendasar adalah penyerahan total semuanya sebagai bentuk ibadah kepada Allah swt.

e. Nilai Keterbukaan.

Akuntabilitas terkait secara langsung dengan keterbukaan. Salah satu syarat terciptanya akuntabilitas ialah keterbukaan. Keterbukaan yang dimaksudkan ialah keterbukaan terhadap apa yang telah dikerjakan kepada pihak-pihak yang berkepentingan atau yang terlibat secara langsung. Keterbukaan mensyaratkan kejujuran dalam mengungkapkan informasi, apa adanya dan bebas dari manipulasi. Kejujuran sebagai 
elemen utama pembentuk nilai keterbukaan berpangkal pada kesadaran bahwa semuanya adalah amanah dari Allah swt yang harus dijaga dan disampaikan kepada pihak-pihak yang berkepentingan. Kontektualisasi keterbukaan pada tingkat Universitas Muhammadiyah Makassar diungkapkan oleh Ibu Ruly:

“...Jadi dasarnya itu keterbukaan, yang tentu nanti kita harapkan akuntabilitasnya bagus. Maka di Unismuh ini ada sistem auditnya, yaaa... audit internalnya ada, audit dari eksternalnya ada... setiap kinerjanya kan nanti diaudit dan hasilnya bisa diketahui oleh semua pihak.. kalau tidak begitu ya,, mana mungkin kita bisa tahu kekurangan atau apa yang terjadi dalam internal kampus... jadi..semuanya harus saling terbuka,, lembaga auditpun harus jujur dan terbuka atas hasilnya..sehingga sekali lagi...harapannya akuntabilitas bisa dicapai..."

Senada dengan ungkapan Ibu Ruly, Ibu Rosleny menuturkan seperti di bawah ini:

“...kalau sosial itu kan landasannya kesadaran kita semua.. kan kita tahu sekali bahwa akuntabilitas itu kan kesesuaian apa yang kita kerjakan dengan aturannya...jadi kalo ada kegiatan sosial yang dilakukan kampus.. ya.. itu kan sudah sesuai karena kita juga menjadi penentu perubahan bagi masyarakat.. jadi,, menurut kami keterbukaan ya.. kita jujur atas apa yang kita lakukan..."

Universitas Muhammadiyah Makassar melihat bahwa keterbukaan informasi tentang kinerja dan seterusnya bisa ditegakkan jika sistem auditnya berjalan dengan baik. Baik sistem audit internal kampus, maupun eksternal kampus, keduanya memiliki kedudukan penting dalam menjamin keterbukaan informasi terkait dengan kinerja Universitas. Kejujuran hasil audit menjadi faktor penentu dalam menegakkan akuntabilitas di ranah kampus. Pernyataan informan Rosleni mengandung makna bahwa akuntabilitas sosial hanya akan terwujud jika semua pihak memiliki kesadaaran untuk mengungkapkan kinerja atau program yang dilakukannya, apakah sesuai dengan aturan atau perintah dari Allah Swt atau tidak. Dengan demikian, menjaga kinerja sosial dari sisi regulasi bumi maupun langit menjadi kunci bagi tegaknya akuntabilitas, dan keterbukaan menjadi media untuk menjembatani itu.

Berikut beberapa bentuk praktik akuntabilitas kinerja sosial yang dilakukan oleh Universitas Muhammadiyah Makassar; memiliki dua desa binaan di Kelurahan Ujung Tanah, Makassar. Kegiatan yang dilakukan di desa binaan antara lain, pendidikan dan pengajaran, serta penyuluhan kesehatan. Universitas juga menyalurkan zakat dan pembagian hewan qurban di lokasi tersebut. Selain itu kegiatan bakti sosial yang secara rutin dilakukan seperti kegiatan Palang Merah Indonesia, pendidikan dan penyuluhan 
untuk anak-anak jalanan, peduli dhuafa, kunjungan ke panti-panti asuhan untuk menyalurkan bantuan serta memberikan pendidikan dan pengajaran kepada anak-anak panti asuhan (kegiatan ini biasanya dilakukan oleh fakultas ilmu pendidikan dan keguruan), dan penanaman bibit pohon di beberapa kabupaten di Sulawesi Selatan (Jeneponto dan Pangkep).

Kinerja sosial Universitas Muhammadiyah Makassar cenderung ke arah pendidikan dan pengajaran sesuai dengan fungsi dari keberadaan perguruan tinggi yaitu untuk mencerdaskan bangsa. Untuk menjalankan fungsi tersebut, yaitu sebagai sebuah lembaga pendidikan dan lembaga kader organisasi, Universitas Muhammadiyah Makassar juga memiliki beberapa sekolah binaan, diantaranya sekolah binaan tingkat menengah pertama dan menengah atas (SMP dan SMA) yang ada di dalam lingkungan universitas. Namanya pun SMP dan SMA Unismuh Makassar. Pesantren Ma'had Al Birr juga merupakan pesantren binaan yang ada dalam lingkungan kampus Universitas Muhammadiyah Makassar. Selain yang berada dalam lingkungan kampus, Universitas Muhammadiyah Makassar juga memiliki sekolah dan pesantren binaan di daerah Busoloro Kabupaten Gowa.

\section{Kesimpulan}

Teologi al Ma'un dalam konteks gerakan Muhammadiyah telah melahirkan banyak produk perubahan yang cukup signifikan dan membanggakan. Teologi tersebut telah berhasil membuat gerakan Muhammadiyah melahirkan sejumlah prestasi yang terdiri dari pendidikan, dan pelayanan sosial. Universitas Muhammadiyah Makassar sebagai salah satu amal usaha Muhammadiyah turut mengilhami spirit teologi Al ma'un ini dengan melakukan upaya-upaya perubahan sosial melalui pendidikan. Pendidikan yang dimaksud bukan hanya berorientasi pada perubahan secara akademik semata, melainkan spiritual juga, sebab universitas merupakan pilar dakwah Muhammadiyah yang juga turut berjuang mewujudkan cita-cita luhur Muhammadiyah. Kiprah Universitas Muhammadiyah Makasssar dalam mewujudkan akuntabilitas sosialnya pada pelayanan sosial telah dibuktikan dengan memiliki beberapa lembaga pendidikan binaan seperti sekolah SMA dan SMP Muhammadiyah yang berada di lingkungan universitas sendiri dan beberapa desa binaan, serta berbagai aktivitas sosial lainnya. Kehadiran Universitas Muhammadiyah Makassar sendiri merupakan berkah bagi masyarakat sekitarnya yang berprofesi sebagai pedagang. Eksistensi Universitas Muhammadiyah Makassar turut 
membantu meningkatkan taraf hidup masyarakat di sekitarnya dan hal ini juga merupakan wujud nyata dari semangat perubahan sosial yang diemban oleh pihak Universitas. Untuk mewujudkan akuntabilitas sosial universitas, ada beberapa nilai mendasar yang terus menerus dijaga dan dijunjung tinggi. Nilai-nilai tersebut antara lain ukhuwah dan keikhlasan dalam menjalankan program kerja, profesionalisme dan kemandirian dalam bekerja, efisiensi dalam menggunakan sumber daya (uang, waktu, dan tenaga), serta keterbukaan atas informasi mengenai kinerja universitas sendiri. Nilai-nilai ini menjadi nilai dasar dalam membentuk akuntabilitas kinerja sosial di tubuh Universitas Muhammadiyah Makassar.

\section{Daftar Pustaka}

Burhani, A. N. (2004). The Muhammadiyah's Attitude To Javanese Culture In 19121930: Appreciation and Tension. Thesis. Universiteit Leiden. Netherlands.

Burhani, A. N. (2013). Teologi Al-Ma'un pada Dua Generasi Muhammadiyah. Artikel Dipublikasikan di Suara Muhammadiyah pada 07 Ramadhan $1434 \mathrm{H}$.

Coulon, A. (2008). Ethnometodology. Sage Publications, Inc. SAGE Research Methods.

Denzin, Norman K., dan Lincoln, Y. S. (2009). Handbook of Qualitative Research (terjemahan). Yogyakarta : Pustaka Pelajar

Huda, S. (2011). Teologi Mustad'afin di Indonesia: Kajian Atas Teologi Muhammadiyah. Jurnal Tsaqafah, 7(2): 345-374

Kholmi, M. (2012). Akuntabilitas dan Pembentukan Perilaku Amanah. Jurnal Studi Ekonomi Islam, 15(1): 63-72

Kurniawan, E. K. (2014). Karakteristik Tata Kelola Keuangan Organisasi Nirlaba. Jurnal Akuntabilitas Organisasi Masyarakat Sipil. Konsil LSM Indonesia

Miles, M. B. dan Huberman, A. M. (1984). Qualitative Data Analysis. London: Sage

Mustapa, L. (2014). Pembaharuan Pendidikan Islam-Studi atas Teologi Sosial Pemikiran KH. Ahmad Dahlan. Jurnal Pembaharuan Pendidikan Islam (JPPI), 1(1): 129142.

Normuslim. (2013). Pemikiran Pendidikan Islam Muhammad Abduh dan Muhammad Iqbal. Anterior Jurnal, 12(2): 97-103.

Rusdiana A. (2013). Akuntabilitas Perguruan Tinggi Islam Swasta. Jurnal Akuntansi, 28(3): 455-468 